\title{
La Visita: Prisons and Survival in Guatemala
}

\author{
Anthony W. Fontes ${ }^{1 \star}$ and Kevin L. O’Neill ${ }^{2}$ \\ ${ }^{1}$ Assistant Professor, School for International Service, American University and ${ }^{2}$ Professor, Department for \\ the Study of Religion and the Centre for Diaspora and Transnational Studies, University of Toronto \\ ${ }^{*}$ Corresponding author. Email: awfontesiv@gmail.com
}

(First published online 17 September 2018)

\begin{abstract}
Based largely on research completed in the North American context, scholars of prisons detail the multiple ways in which carceral practices extend beyond prison walls to transform a wide variety of spaces, ultimately assessing how carceral imaginaries inhabit the most intimate aspects of everyday life. In Latin America, this division between the inside and the outside of prison breaks down even further when read from the perspective of survival. Drawing on ethnographic research across Guatemala's penitentiary system, this article explores how the deep interdependencies that develop between male prisoners and female visitors sustain not just these prisoners and their visitors but also the prison system itself.
\end{abstract}

Keywords: Guatemala; prisons; drugs; trafficking; women

\section{Introduction}

Prison studies has made it eminently clear that the prison is not separate from the rest of society. Based largely on research completed in the North American context, scholars of prisons detail the multiple ways in which carceral practices extend beyond prison walls to transform a wide variety of spaces, ultimately assessing how carceral imaginaries inhabit the most intimate aspects of everyday life. ${ }^{1}$ There is an added dimension to this observation, however, that is particularly visible in Latin America: survival.

In Guatemala, the site of this study, prisoners and non-prisoners depend on each other in the daily business of survival. What is more, these relationships undergird the very survival of the prison system itself. These interdependencies come into stark relief with a focus on the labour that female visitors provide for incarcerated

\footnotetext{
${ }^{1}$ See, for example, Loïc Wacquant, 'Deadly Symbiosis: When Ghetto and Prison Meet and Mesh', Punishment \& Society, 3: 1 (2001), pp. 95-133; Dominique Moran, 'Between Outside and Inside? Prison Visiting Rooms as Liminal Carceral Spaces', GeoJournal, 78: 2 (2013), pp. 339-51; Megan Comfort, Doing Time Together: Love and Family in the Shadow of the Prison (Chicago, IL: University of Chicago Press, 2007); Marc Mauer and Meda Chesney-Lind (eds.), Invisible Punishment: The Collateral Consequences of Mass Imprisonment (New York: The New Press, 2002).

(C) Cambridge University Press 2018
} 
men. Of interest here is that this labour sustains not just prisoners and these visitors but also an overcrowded and underfunded prison system in two incontrovertible ways. The first is that female visitors triage an extreme lack of state resources by feeding, clothing and caring for prisoners. The second is that female visitors smuggle drugs and cell phones into the prison setting. Without this labour and these two illicit commodities, Guatemala's prison system and its prisoners would not endure while these women would also lose access to an essential source of income.

This article asks two interrelated questions: How and to what effect has the survival of the Guatemalan prison system, its prisoners and its visitors become dependent upon the labour of female visitors? An answer is found through a close examination of prisoners' visitation privileges, or la visita. On visiting days, in all but Guatemala's maximum-security prisons, hundreds of women enter the prison setting as mothers, daughters, sisters, lovers, wives and sex workers. These visits are prisoners' principal point of contact with the world beyond the prison gates and, thus, the primary means by which drugs and cell phones as well as food, clothing and care enter the prison system. The gendered realities of these exchanges also create the conditions for women to pursue emotional and entrepreneurial opportunities inside the prison, even as they are forced to navigate profound legal and health-related risks. We argue, then, that la visita demonstrates most lucidly the symbiotic labour arrangements that structure prison life, with the circulation of material goods deeply reliant on the circulation of affect. ${ }^{2}$ Such configurations illuminate how prison life and life on the so-called 'outside' interpenetrate one another for the sake of survival.

We base our argument on fieldwork that extends across multiple years and various prisons, but focuses on a single case study: a relationship between a young woman whom we call Sofía and a prisoner whom we call Carlos. While the ethnographic specificity of their relationship operates at a relatively small scale and amid a decidedly unique post-war context, Sofía's relationship with Carlos animates the oftentimes intimate perils and possibilities for women inside the penitentiary system. ${ }^{3}$ It is an ethnographic portrait framed by a combined 15 years of fieldwork in prisons and sites of extrajudicial imprisonment in post-war Guatemala. With the

\footnotetext{
${ }^{2}$ By affect we mean the emotional work that goes into managing the feelings of others. Studies of immaterial labour have focused on the kinds of emotional work that sex workers, waitresses and airline hostesses pursue in their respective jobs. They must handle their client to make sure that the customer always feels right, and this often involves managing their own feelings to create a particular emotional state in another person. Call centre workers, waitresses and airline hostesses, for example, must hold their tongues, so to speak, to maintain a good rapport. See Michael Hardt, 'Affective Labor', boundary 2, 26: 2 (1999), pp. 89-100; Robin Leidner, Fast Food, Fast Talk: Service Work and the Routinization of Everyday Life (Berkeley, CA: University of California Press, 1993); Wendy Chapkis, Live Sex Acts: Women Performing Erotic Labor (London: Routledge, 1996); Greta Foff Paules, Dishing it Out: Power and Resistance Among Waitresses in a New Jersey Restaurant (Philadelphia, PA: Temple University Press, 1991).

${ }^{3}$ Important ethnographies organised around the life of one person include Ruth Behar, Translated Woman: Crossing the Border with Esperanza's Story, 10th anniv. ed. (Boston, MA: Beacon Press, 2003); João Biehl, Vita: Life in a Zone of Social Abandonment (Berkeley, CA: University of California Press, 2005); Karen McCarthy Brown, Mama Lola: A Vodou Priestess in Brooklyn, rev. ed. (Berkeley, CA: University of California Press, 2001); Vincent Crapanzano, Tuhami: Portrait of a Moroccan (Chicago, IL: Univeristy of Chicago Press, 1985); Robert Desjarlais, Sensory Biographies: Lives and Deaths among Nepal's Yolmo Buddhists (Berkeley, CA: University of California Press, 2003); Angela Garcia, The
} 
authors' access to prisons facilitated by visitation privileges, the fieldwork for this article included extensive interviews and long stretches of participant observation within several of Guatemala's prisons, including Pavón, Pavoncito, Cantel, Canadá, Boquerón, El Preventivo and the Centro de Orientación Femenino (Women's Detention Centre, COF), as well as formal interviews with the Dirección General del Sistema Penitenciaro (Directorate-General for the Penitentiary System, DGSP) and El Preventivo prison. Both authors completed fieldwork together for this article in the June and July of 2014, which culminated in a presidential report on drugs in the Guatemalan prison system. ${ }^{4}$

This extended ethnographic engagement also took place against the backdrop of an already established anthropology of violence. This includes the work of Ruth Behar, Nancy Scheper-Hughes and Philippe Bourgois as well as a more recent generation of ethnographers whose research engages directly with debates over the representation of violence in Latin America. ${ }^{5}$ The work of Ellen Moodie in neighbouring El Salvador proves instructive, especially her commitment to avoiding tropes of male delinquency. As Moodie reminds the anthropologist and by extension the scholar of Latin American studies, 'the social obsession about crime and criminals ... is not just about crime and criminals'. 6 Our efforts at representing Sofía and Carlos aspire towards an ethnographic portrait that sidesteps an unreflexive interest in violence. As a model for this approach, we look towards the work of Angela Garcia, whose 2016 article on an individual prisoner in New Mexico provides a particularly rich understanding of the emotional complexities of incarceration through a single informant. ${ }^{7}$ One central challenge in situating ourselves within this literature, however, has been to modulate research in the North American prison setting to parallel efforts in Guatemala, where degraded institutions and severe insecurity can often make struggles for survival more explicit than in the North American context. The prison that held Carlos, for example, operates at over 300 per cent capacity and routinely erupts into riots. ${ }^{8}$ One in 2015 left nine prisoners dead (four of them decapitated). ${ }^{9}$ At the same time,

Pastoral Clinic: Addiction and Disposession along the Rio Grande (Berkeley, CA: University of California Press, 2010).

${ }^{4}$ Anthony Fontes, Kevin O’Neill and Corina Giacomello, 'El impacto de las políticas de drogas en los cárceles de Guatemala' (The Impact of Drug Policy in Guatemalan Prisons), Open Society Foundations and the Social Science Research Council, in cooperation with the Guatemalan Presidential Drug Policy Commission (June 2015).

${ }^{5}$ Behar, Translated Woman; Nancy Scheper-Hughes, Death Without Weeping: The Violence of Everyday Life in Brazil (Berkeley, CA: University of California Press, 1993); Philippe Bourgois, In Search of Respect: Selling Crack in El Barrio (Cambridge: Cambridge University Press, 2003). See also Elana Zilberg, Spaces of Detention: The Making of a Transnational Gang Crisis Between Los Angeles and San Salvador (Durham, NC: Duke University Press, 2011); Jason De Leon, The Land of Open Graves: Living and Dying on the Migrant Trail (Berkeley, CA: University of California Press, 2015).

${ }^{6}$ See Ellen Moodie, El Salvador in the Aftermath of Peace: Crime, Uncertainty, and the Transition to Democracy (Philadelphia, PA: University of Pennsylvania Press, 2010), p. 171.

${ }^{7}$ Angela Garcia, 'The Blue Years: An Ethnography of a Prison Archive', Cultural Anthropology, 31: 4 (2016), pp. 571-94.

${ }^{8}$ Centro de Investigaciones Económicas Nacionales (CIEN), 'El sistema penitenciario guatemalteco - un diagnóstico’ (Guatemala: Centro de Investigaciones Económicas Nacionales, 2011).

${ }^{9}$ See Anthony W. Fontes, Mortal Doubt: Transnational Gangs and Social Order in Guatemala City (Berkeley, CA: University of California Press, 2018). 
Sofía's home is located in one of the most violent neighbourhoods in Guatemala City, with a homicide rate nearly 40 times the US average (190 homicides per 100,000 inhabitants). ${ }^{10}$

The article unfolds in six parts. Part one situates this article within the growing field of prison studies and its incipient connexions to carceral conditions in Latin America. Part two introduces readers to Sofía and Carlos while part three establishes the history and growth of the Guatemalan prison system. The next three sections draw on fieldwork. Part four details the connexions that women make with prisoners via cell phones while part five documents the centrality of women's bodies to prison drug economies. Part six then explores the emotional work of smuggling contraband into the prison. The conclusion follows Sofía's eventual arrest and Carlos' murder, leaving Sofía to raise their infant son on her own, and providing a final reflection on the conditions of survival that necessitate the precarious relationships between prisoners and non-prisoners in Latin America.

\section{Prison Studies and/in Latin America}

Prison studies has long presumed a division between the prison and society, with prison life often imagined as completely set apart from wider society. Erving Goffman's notion of the total institution is one obvious point of reference. So too is Michel Foucault's carceral archipelago, which may acknowledge that penitentiary techniques extend into the entire social body, but nonetheless understands these techniques as contained within architecturally specific sites of discipline: the factory, school and reformatory, for example. ${ }^{11}$ Acknowledging how state practices of surveillance and punishment extend beyond such institutions, a new generation of scholars has focused on what Loïc Wacqant calls a 'carceral continuum', which links prisoners and prison life to the marginalised urban communities from which they are drawn. ${ }^{12}$ This growing body of research details the intimate relationships that exist between life inside prisons and life on the outside.

One important point of reference is the work of Megan Comfort, whose fieldwork with women visiting men at San Quentin State Prison in the United States demonstrates how this presumed boundary between home and prison dissolves in ways that turn these visitors into what Comfort calls 'quasi-inmates.'. Scholars have extended this observation to assess the liminal nature of prison visiting rooms, the social life portrayed in prisoner photographs, and even how

\footnotetext{
${ }^{10}$ The exact urban homicide rate is disputed. National estimates hover around $80 / 100,000$ and, depending on where the borders of the capital are drawn, the city's homicide rate ranges from 100/100,000 to 190/ 100,000. The above estimate is cited from interviews with Peter Marchetti, lead researcher with AVANSCO in Guatemala, 15 July 2010.

${ }^{11}$ Erving Goffman, Asylums: Essays on the Social Situation of Mental Patients and Other Inmates (New York: Routledge, 2017); Michel Foucault, Discipline and Punish: The Birth of the Prison (New York: Knopf Doubleday, 2012), p. 298. See also Philippe Combessie, 'Marking the Carceral Boundary. Penal Stigma in the Long Shadow of the Prison', Ethnography, 3: 4 (2002), pp. 535-55.

${ }^{12}$ Wacquant, 'Deadly Symbiosis: When Ghetto and Prison Meet and Mesh', p. 97.

${ }^{13}$ Comfort, Doing Time Together: Love and Family in the Shadow of the Prison, p. 15.
} 
mandatory sentencing and prison privatisation in the United States has resulted in the 'mass incarceration of US citizens' .

In Latin America, scholars of prisons have engaged in a different set of questions than their North American counterparts. Their interests include expanding rates of incarceration, the implementation of structural adjustment, prohibitionist drug policies, the militarisation and securitisation of Latin American states and the expansion of a US-style industrial prison complex. ${ }^{15}$ Key to this conversation has been the reoccurring observation that states throughout Latin America routinely fail to isolate prisoners effectively. Particularly in Central America and Brazil, where powerful prison-based criminal organisations present open challenges to the rule of law, prisons have become understood as the 'hole at the centre of the state'. ${ }^{16}$ Prisoners routinely take advantage of aged infrastructure and prison staff's participation in illicit businesses not only to create self-governing organisations inside of prison but also to project their influence into urban communities. Despite this illuminating focus on the circulation of prison power in the non-prison world, the study of Latin American prisons (with few exceptions) has not delved into the more intimate and everyday linkages between life on the inside and life on the outside of prisons, leaving in place the presumption of distinct social worlds divided by penitentiary walls. ${ }^{17}$

Research on women prisoners in Latin America has the potential to bridge these two literatures. As the work of Corina Giacomello makes eminently clear, there has been a steady rise since the 1990s of women imprisoned for drug-related offences, with convictions tied to women's growing participation in drug economies as con-

\footnotetext{
${ }^{14}$ Moran, 'Between Outside and Inside? Prison Visiting Rooms as Liminal Carceral Spaces'; Nicole R. Fleetwood, 'Posing in Prison: Family Photographs, Emotional Labor, and Carceral Intimacy', Public Culture, 27: 3 (2015), pp. 487-511; Mauer and Chesney-Lind (eds.), Invisible Punishment: The Collateral Consequences of Mass Imprisonment.

${ }^{15}$ Loïc Wacquant, 'The Militarization of Urban Marginality: Lessons from the Brazilian Metropolis', International Political Sociology, 2 (2008), pp. 56-64; Jeffrey Ian Ross (ed.), The Globalization of Supermax Prisons (New Brunswick, NJ: Rutgers University Press, 2013); Chris Garces, Tomas Martin and Sacha Darke, 'Informal Prison Dynamics in Africa and Latin America', Criminal Justice Matters, 91: 1 (2013), pp. 26-7.

${ }^{16}$ Sacha Darke, 'Managing without Guards in a Brazilian Police Lockup', Focaal, 68 (2014), pp. 55-67; Benjamin Lessing, 'Inside Out: The Challenge of Prison-Based Criminal Organizations' (Washington, DC: Brookings Institution, 2016), available at www.brookings.edu/wp-content/uploads/2016/09/ fp_20160927_prison_based_organizations.pdf (last access 11 July 2018); Graham Denyer-Willis, 'Deadly Symbiosis? The PCC, the State and the Institutionalization of Violence in São Paulo', in Gareth A. Jones and Dennis Rodgers (eds.), Youth Violence in Latin America: Gangs and Juvenile Justice in Perspective (New York: Palgrave-Macmillan, 2009), pp. 167-82; José Miguel Cruz, 'Central American maras: From Youth Street Gangs to Transnational Protection Rackets', Global Crime, 11: 4 (2010), pp. 379-98.

${ }^{17}$ These notable exceptions include Jon Horne Carter's work in Honduran prisons, where he identifies not only how some prisoners are able to project their influence beyond prison walls, but also how prison economies are deeply enmeshed with actors and communities on the outside. See Jon Horne Carter, 'Neoliberal Penology and Criminal Finance in Honduras', Prison Service Journal, 229 (Jan. 2017), pp. 10-14. See also Hollis Moore, 'Imprisonment and (Un)Relatedness in Northeast Brazil', unpubl. PhD diss., University of Toronto, 2017; Kristen Drybread, 'Documents of Indiscipline and Indifference: The Violence of Bureaucracy in a Brazilian Juvenile Prison', American Ethnologist, 43: 3 (2016), pp. 411-23.
} 
sumers, dealers and transporters. ${ }^{18}$ And while there are more men than women incarcerated in Latin America, the incarceration of the latter is increasing at a faster pace. A 2015 report states that the population of women prisoners in Latin America rose 51.6 per cent between 2000 and 2015, compared to 20 per cent for men. ${ }^{19}$ While this demographic trend is important, it nonetheless misses women's essential role in shaping prison life across penitentiary systems as visitors. The research also fails to make it explicit that the labour of these female visitors blurs any concrete distinction between the prison and the rest of society while also stopping short of establishing the interdependency that such arrangements create. As our research makes clear, the women moving drugs and cell phones into the prison setting depend on the prison, just as the prison and those inside the prison depend on these women.

The severe insecurity, institutional decay and socio-economic inequality of postwar Guatemala render ethnographically observable these interdependent efforts at survival. More than two decades after the end of Central America's longest and bloodiest civil war (1960-96), Guatemala remains one of Latin America's poorest, most unequal and most violent societies. ${ }^{20}$ Formal employment is scarce, especially for the poor and undereducated, driving most Guatemalans into the informal market where wages rarely reach the equivalent of US\$1-2 per day. ${ }^{21}$ At the same time,

\footnotetext{
${ }^{18}$ Corina Giacomello, Género, drogas y prisión: experiencias de mujeres privadas de su libertad en México (Mexico City: Tirant lo Blanch, 2013); see also Washington Office on Latin America (WOLA), International Drug Policy Consortium, Dejusticia, and Inter-American Commission of Women of the Organization of American States (OAS), 'Women, Drug Policies, and Incarceration: a Guide for Policy Reform in Latin America and the Caribbean' (Washington, DC: OAS, 2016), available at www.oas.org/ en/cim/docs/womendrugsincarceration-en.pdf (last access 11 July 2018); Elizabeth Almeda, Corregir y castigar: el ayer y hoy de las cárceles de mujeres (Barcelona: Ediciones Bellaterra, 2002); Alejandro Corda, Encarcelamiento por delitos relacionado con estupefacientes en Argentina (Buenos Aires: Intercambios Asociación Civil, University of Buenos Aires, 2011); Carmen Antony, 'Mujeres invisibles: las cárceles femeninas en América Latina', Nueva Sociedad, 208 (March-April 2007), pp. 73-85, 180; Jennifer Fleetwood, Drug Mules: Women in the International Cocaine Trade (London: Palgrave Macmillan, 2014); Rosalva Aída Hernández Castillo (coord.), 'Bajo la sombra del Guamúchil. Historias de vida de mujeres indígenas y campesinas en prisión' (Mexico City: CIESAS, IWGIA, Ore-media, 2010); Andreina Isabel Torres Angarita, 'Drogas y criminalidad femenina en Ecuador: el amor como un factor explicativo en la experiencia de las mulas' (Quito: FLACSO Ecuador, 2007).

${ }^{19}$ Roy Walmsley, 'World Female Imprisonment List' (London: Institute for Criminal Policy Research at Birkbeck, University of London, Oct. 2015), pp. 2 and 13, cited in WOLA et al., 'Women, Drug Policies, and Incarceration: A Guide for Policy Reform in Latin America and the Caribbean'.

${ }^{20}$ In recent years, Guatemala ranks $11^{\text {th }}$ among the world's most unequal countries (CIA World Factbook, 'Country Comparison: Distribution of Family Income Gini Index', available at www.cia.gov/ library/publications/the-world-factbook/rankorder/2172rank.html, last access 11 July 2018) and is consistently among the top five most murderous countries in the world (measured by homicides/100,000). Inequality in Guatemala is also multidimensional. Alongside severe socio-economic inequality, Guatemala has extremely high rates of gender inequality, with a ranking of 125 out of 188 countries in terms of gender equality (United Nations Development Programme, 'Human Development Reports: Table 5: Gender Inequality Index', available at http://hdr.undp.org/en/composite/GII, last access 11 July 2018).

${ }^{21}$ See Danish Trade Union Council for International Development Cooperation, 'Guatemala: Labour Market Profile 2014' (Copenhagen: Danish Trade Union Council for International Development Cooperation, n.d.), p. 14, available at https://od.dk/sites/default/files/undervisning/arbejdsmarkedsprofil_0.pdf (last access 11 July 2018).
} 
the nation's prison system is broken. With one of the lowest tax rates in the western hemisphere and widespread distrust against increasingly criminalised populations, the state has had little motivation to invest the time and money needed to update the prison system, relying on a make-do approach often described as neoliberal.

The severe lack of state resources to keep prisoners alive has made their survival dependent on female visitors. At the same time, the absence of adequate employment for poor Guatemalans makes prisons sites of economic opportunity. Such interdependencies illuminate a carceral condition that neither begins nor ends at the prison gates, but links prison life and the outside world through the arduous (and sometimes intimate) business of survival. Such conditions have consequences - for prisoners, the prison system and, most acutely, for the women who run the risk of their own incarceration by pursuing the opportunities that arise in male prisons.

\section{Sofía and Carlos}

Sofía was born and raised in Zone 18, a poor urban neighbourhood. Shortly after her birth, her father quit drinking and both her parents converted to Evangelical Christianity. She attended school until she was 14, but then her first child was born. She subsequently worked in a factory in order to support her child and her family. She laboured as much as 18 hours a day, making roughly Q2,000 (or US\$250) a month throughout a second pregnancy. "Then my little one was born', she said. 'Then I worked from 7 in the morning to 7 at night. Maybe a little more, when they gave us extra hours. But I left because the boss there was ...' she paused, a look of disgust passed across her face: 'He was one of those people who, when a new girl arrived, would make her do what he wanted, you know?' She tried working in the informal market, and even participated in a gang extortion racket, but she was unable to make ends meet. ${ }^{22}$

Sofía's eventual partner, Carlos, was born in Guatemala City, but migrated with his parents to the United States when he was four years old. As a teenager, he got involved with gangs and drug trafficking in Los Angeles, California, was arrested multiple times and was eventually deported back to Guatemala at 24 years of age. His only surviving relative in the United States was his ageing father, and he had no family or friends in Guatemala, but his fluent command of English landed him a job in an international call centre in Guatemala City. Though he was able to earn a decent salary at the call centre, Carlos said, he kept up a fast-paced lifestyle that drew him back into crime. Carlos was eventually arrested in Guatemala in 2010 and sentenced to eight years behind bars for carjacking. It was in prison that he and Sofía met shortly after she began smuggling contraband for another prisoner.

\footnotetext{
${ }^{22}$ Sofía's involvement in an extortion racket links her to another understudied but important phenomenon involving women and illicit markets. Analysts and scholars have observed a marked increase in female involvement in extortion rackets, one of Central America's most common and most feared criminal activities. Though male gang members and prisoners are the most widely blamed for the violence associated with extortion rackets, more and more women are involved in collecting and distributing extortion tithes, as well as in the surveillance and communication involved in creating and maintaining successful extortion rackets. See Fontes, 'Extorted Life: Protection Rackets in Guatemala City', Public Culture, 28: 3 (2016), pp. 593-616 and Cruz, 'Central American maras: From Youth Street Gangs to Transnational Protection Rackets'.
} 
'We've been together a little more than a year', Sofía said, cradling her new-born son. We spoke in her family's home on the outskirts of Guatemala City in mid-2014. 'The first three months were miraculous', she remembered: 'Three beautiful months. But then, ten months of torture, humiliations, fights. I tried to leave him. Lots of times. But when I did, he cut his veins. He cut up his whole arm, where he has those tattoos.' Sofía slid her hand down her arm, mapping his cuts onto her skin. 'He even said, before I had the baby, "I hope you die! And I hope the baby dies too!"' Sofía grew quiet, and then said, 'So I hung up on him.' Sofía and Carlos spoke every day, sometimes late into the night, with a cell phone that Sofía smuggled into the prison.

Carlos and Sofía, up until his death, were in a committed relationship with each other. However, Carlos' incarceration, and his total reliance upon Sofía's support, left him perpetually unsteady. 'It's like a storm', he admitted as we talked in the prison courtyard. 'But I've told her a bunch of times: "Look, if you don't wanna be with me, then just tell me. If you find another man, then just tell me."' His apparent reasonableness then turned into rage: "Because if you play with my feelings, I'll kill you."'

This relationship, born and nurtured during Carlos' incarceration, sustained not just Carlos and Sofía, or even the baby they conceived during a conjugal visit, but also a vast network of prisoners, friends and family. For Sofía did not smuggle just one cell phone into the prison but rather dozens of them, along with kilogrammes of marijuana and cocaine. She did this every week, allowing Carlos to sell these products to other prisoners at a steep mark-up, and taking a cut of the profits.

Sofía's foray into prison drug smuggling was how they first met. She was working with another prisoner, but the man proved to be an unreliable and even abusive business partner. After she started working with Carlos, he promised an altogether different arrangement: 'I told her, it wasn't gonna just be: "here's your payment for bringing me this." No. "You bring me in a pound of weed, and half of what we make is for you." His voice softened. 'I told her, "We are in this together." Given the history and the context, this was not only a dashingly romantic gesture, but also a genuinely tempting business offer that makes clear the affective dimensions of prison economies. ${ }^{23}$

La visita proved to be key to their relationship. It is also critical to the prison economy, with hundreds of women earning their living by participating in the illicit side of these exchanges at the risk of their own incarceration. Drug trafficking carries a minimum five-year prison sentence. But complicating these affairs is the fact that - as in Sofía's case - the work of trafficking is often prompted by and entangled with bonds of affection, making both women's physical and emotional labour vital to the survival of prisoners and the prison. 'I enter stuff for him because of my heart', Sofía said. 'I never tell him, “No, I can't. No, I don't want this." I risk myself so much.' Carlos also claimed to be committed to her, their child and their life together. 'We're trying to change our lives', Carlos said in defence of their hustle. 'I'm trying to make a better future for us.' Crucially, Carlos' desperation and the defiance that Sofía strikes are not individualised emotions or autonomous states

\footnotetext{
${ }^{23}$ For an understanding of affective capitalism, see Analiese Richard and Daromir Rudnyckyj, 'Economies of Affect', Journal of the Royal Anthropological Institute, 15: 1 (March 2009), pp. 57-77.
} 
of feeling. Instead, the muddled contours of their relationship open a window into a deeply structural set of conditions that organise Guatemala's penitentiary system. Women like Sofía provide invaluable labour and essential resources to prisoners such as Carlos that the state does not provide. ${ }^{24}$ In turn, for women like Sofía, the penitentiary system's total reliance on these visits makes the male prison a space of economic and emotional opportunities. Sofía could not make a living without Carlos or the prison, but the prison itself could not endure without Sofía.

\section{Porous Prisons}

As the penitentiary system lingers in a perpetual state of crisis, Guatemala has seen the increased visibility of women, such as Sofía, offset the dearth of resources normally provisioned by the state. Guatemala's civil war officially ended in 1996: 36 years of intermittent bloodshed spiking in the early 1980s with genocidal scorched-earth campaigns. ${ }^{25}$ The numbers alone tell a brutal tale: 250,000 killed and 45,000 disappeared out of a population of seven million. ${ }^{26}$ During decades of political conflict, the construction and maintenance of prisons were not a government priority. Until 1985, most prison facilities were remanded to military control. ${ }^{27}$ During this time, incarceration was not the preferred solution for imposing law and order. State authorities were far more likely to execute or disappear suspected criminals and political subversives than incarcerate them, while communities across the country tended to judge and punish people in the name of vigilante justice. $^{28}$ This tendency to deal with crime and suspected criminals extra-judicially left Guatemala wholly unprepared to deal with the unprecedented rise in violent crime in the post-war period.

Today, the Guatemalan penitentiary system has 22 separate prison facilities. Over the last two decades, the diversity of the system's form and function has expanded as the government struggles to deal with the exponential rise in post-war violent crime. ${ }^{29}$ Modelled on US-style maximum-security structures, Guatemala

\footnotetext{
${ }^{24}$ For a sense of Guatemala's declining state resources, see a new generation of scholarship on Guatemala that includes Edward F. Fischer and Peter Benson, Broccoli and Desire: Global Connections and Maya Struggles in Postwar Guatemala (Stanford, CA: Stanford University Press, 2006); Kedron Thomas, Regulating Style: Intellectual Property Law and the Business of Fashion in Guatemala (Berkeley, CA: University of California Press, 2016).

${ }^{25}$ Victoria Sanford, Buried Secrets: Truth and Human Rights in Guatemala (New York: Palgrave Macmillan, 2003).

${ }^{26}$ Comisión para el Esclarecimiento Histórico (CEH), 'Guatemala memoria del silencio: conclusiones y recomendaciones’ (Guatemala: Comisión para el Esclarecimiento Histórico, June 1999).

${ }^{27} \mathrm{CIEN}$, 'El sistema penitenciario guatemalteco', p. 37.

${ }^{28} \mathrm{ODHA}$, 'Guatemala, nunca más: Report of the Project for the Recuperation of Historical Memory (REMHI)', vols. 1-4 (Guatemala: Archbishop's Office of Human Rights, 1998); Jean Franco, 'Killing Priests, Nuns, Women, Children', in Nancy Scheper-Hughes and Philippe Bourgois (eds.), Violence in War and Peace: An Anthology (Oxford: Blackwell, 2004), pp. 196-99; Beatriz Manz, Paradise in Ashes: A Guatemalan Journey of Courage, Terror, and Hope (Berkeley, CA: University of California Press, 2004).

${ }^{29}$ Cynthia J. Arnason, Eric L. Olson, Steven S. Dudley et al., 'Organized Crime in Central America: The Northern Triangle’ (Washington, DC: Woodrow Wilson International Center for Scholars, 2011); Steven S. Dudley, 'Transnational Crime in Mexico and Central America: Its Evolution and Role in International Migration' (Washington, DC: Migration Policy Institute, Nov. 2012).
} 
constructed its first maximum-security facility in 1999. Over the next decade, the state built two more in an effort to stop incarcerated gang leaders and organised criminal groups from continuing illicit operations from behind bars. ${ }^{30}$ Although prosecution rates for murder, domestic violence and other serious crimes have remained at less than ten per cent over the last 20 years, during this time the prison population has tripled, as Table 1 reveals, even as Guatemala boasts one of the lowest rates of incarceration in the western hemisphere. ${ }^{31}$ What is more, because of enormous backlogs in the judicial system, more than half of those behind bars have not been sentenced. ${ }^{32} \mathrm{~A}$ surging pre-trial detainee population waits years to see a day in court.

Despite the enormous impact of violent crime in post-war Guatemala, the state has had little motivation for investing the time and money needed to revamp its current system. Spending on prisons equals 0.739 per cent of the state's annual budget. ${ }^{33}$ Today, the prison system also runs at more than 250 per cent capacity with an overpopulation rate of above 500 per cent in facilities housing pre-trial detainees. ${ }^{34}$ More than half of the 22 prisons that were built between 1950 and 1980 have not been improved to keep up with growing prison populations or technological advances, such as cell phones. ${ }^{35}$ Most lack even rudimentary security technologies, such as functional metal detectors, body scanners and drug dogs. To further impress how resource-impoverished Guatemalan prisons are, the entire system employs a meagre 21 educators, 12 psychologists, 16 medical doctors and 18 social workers across the 22 geographically dispersed prison structures, with the vast majority of these employees serving those structures in or around the capital city. ${ }^{36}$

La visita has thus emerged as a practice that fundamentally sustains the prison system, offering prisoners access to resources that the state does not and cannot provide them. Perhaps this is why, in comparison with the US prison system, visiting privileges in Guatemalan prisons are strikingly liberal. In general, prisoners have access to visitors several days a week. There are also very few restrictions on what visitors can bring into the prison. Before smuggling contraband into the

\footnotetext{
${ }^{30} \mathrm{CIEN}$, 'El sistema penitenciario guatemalteco'.

${ }^{31}$ International Centre for Prison Studies, 'Highest to Lowest: Prison Population Rate' (n.d.), available at www.prisonstudies.org/highest-to-lowest/prison_population_rate?field_region_taxonomy_tid=18 (last access 11 July 2018); OAS, 'Situación actual del sistema carcelario guatemalteco' (Washington, DC: Organization of American States, n.d.).

${ }^{32} \mathrm{CIEN}$, 'Postura 20: entendiendo el fenómeno de extorsiones en Guatemala' (2014), available at https:// es.scribd.com/doc/247016209/Entendiendo-el-Fenomeno-de-Extorsiones-en-Guatemala (last access 11 July 2018).

${ }^{33}$ Guatemalan Ministry of the Interior, 'Request for Information \#546' (1 June 2015).

${ }^{34} \mathrm{See}$ CIEN, 'El sistema penitenciario guatemalteco'; CIEN, 'Postura 6: un mejor futuro para los adolescentes privados de libertad' (2012), available at https://es.scribd.com/doc/147267680/Postura-6-Un-mejorfuturo-para-los-adolescentes-privados-de-libertad (last access 11 July 2018).

${ }^{35}$ In the last ten years, the Guatemalan government has made numerous attempts to block cell phone signals in prison facilities. In 2015, for example, the government contracted cell phone companies to construct signal-blocking towers located on the perimeter of several medium- and maximum-security prisons. While they initially functioned in at least some facilities, recent reports from inmates and prison directors indicate that rain and wind have limited their reach and made cell phone communication between inmates and the outside world possible once again.

${ }^{36}$ These numbers are from a response given by the Guatemalan Ministry of Government to a solicitation for information requested on 1 June 2015.
} 
Table 1. Evolution of the Prison Population 2000-2015

\begin{tabular}{|ccc|}
\hline Year & Imprisoned population & Incarceration rate/100,000 \\
\hline 2000 & 6,974 & 62 \\
\hline 2002 & 8,077 & 69 \\
\hline 2004 & 8,698 & 70 \\
\hline 2006 & 7,477 & 57 \\
\hline 2008 & 8,158 & 60 \\
\hline 2010 & 11,148 & 78 \\
\hline 2012 & 15,013 & 100 \\
\hline 2014 & 18,425 & 115 \\
\hline 2015 & 18,726 & 116 \\
\hline
\end{tabular}

Source: International Centre for Prison Studies, 'World Prison Brief: Guatemala' (2015), available at www.prisonstudies. org/country/guatemala (last access 12 July 2018).

prison for Carlos, for example, Sofía brought him soap, toilet paper, toothpaste and antibiotic ointment for an infected cut. But this is just the beginning. The catalogue of commodities that la visita provides is lengthy. They include fresh vegetables, flour, oil and other staples, from home-cooked meals to candies and snacks, which help supplement the poor and often unsanitary food that prisoners receive from the state. Visitors also funnel in all kinds of medicines: insulin, aspirin, antihistamines and skin ointments, for example, as well as goods such as shaving razors, magazines, batteries, stereos, tools, watches, jewellery and clothing.

Inmates must earn money to survive prison life and thus depend upon visiting days for their equipment and materials. Prisoners operate restaurants, bakeries, barbershops, exercise gyms, laundry services, shoe repair shops and painting studios inside these facilities. They raise pigs, chickens, goats, fighting cocks, and raccoons. Many even grow their own food on small farm plots, and visiting days allow these prisoners to gain access to feed, fertiliser and seeds. In some prisons, there are inmate-run pig and chicken feed stores, carpentry workshops, tortilla vendors and hammock-weaving factories. Without visiting days, none of these prisoners would have access to such resources as wood, metal, paint, leather, concrete and tools to run any of these small businesses. La visita also allows for cash to enter a currency-starved prison economy; when prison gates are open to the public, inmates do their best business, if not their only business. Even if visitors do not bring their own cash, these visits inspire those inmates with money to purchase gifts for their visitors. La visita also ensures that prisoner-made goods - lamps, hammocks and candles - are brought to markets on the outside.

But most importantly, these visits give prisoners access to two staple commodities of Guatemalan prison life: drugs and cell phones. Driven by a combination of potential profits, devotion to their partners and lack of opportunities in the formal economy, wives, girlfriends and sex workers regularly smuggle contraband through prison gates by way of their bodies. Not only are cavity searches infrequent but also, by the prison administrators' own admissions, as much as 30 per cent of prison staff 
participates in drug trafficking as well. Prison guards augment their own paltry salaries with kickbacks, turning a blind eye at the right moment to the right woman. This makes the practice of moving contraband quite routine, but not without considerable, if uneven, risks for those like Carlos and Sofía. They lack the means to establish reliable collaborators among prison officials. Typically only drug traffickers with money and connexions can afford to keep prison staff on their payroll. Thus the vast majority of prisoner drug dealers, like Carlos, are small-time and become dependent upon women like Sofía, who risk their health and future, to maintain their own survival as inmates.

And yet despite these risks, Sofía and Carlos stayed in business for as long as they could because neither felt they had more appealing options. Formal prison jobs pay no more than US $\$ 0.25$ an hour, and Sofía could have laboured as domestic help or as a factory worker for slightly more; but neither could have earned a living wage, and neither job would have propelled them towards their dreams of getting married in a church. 'Sofía wanted to get married in here', Carlos said as we spoke in the prison courtyard. 'With the pastor and the director as witness. But I don't wanna ruin that. That's a special date.' All they needed was money. Before getting arrested five years earlier, Carlos earned a solid middle-class salary as a customer service agent for a bilingual international call centre in Guatemala. ${ }^{37}$ While in prison, before his release, Carlos had planned to return to this work: 'I can support Sofía and my kid with my wage at the call centre, paying our rent and our food and the kid's school.' The two planned to get married then. 'We're gonna do it how I always dreamed it, how my sisters do it and my brothers do it. Go to church, and after church the reception and the hotel.'

\section{Cellular Connexions}

Through their capacity to smuggle contraband past prison gates, women like Sofía are responsible for the provision of cell phones to Guatemalan prisoners. Small and inexpensive (approximately US\$20), a cell phone can sell for up to ten times its market value inside the prison. ${ }^{38}$ Cell phones also make more lucrative ventures possible; they allow prisoners to coordinate efforts at drug trafficking, maintain profitable extortion rackets and pursue tele-promotion scams. The buying and selling of cell phone minutes - which can be transferred from phone to phone or purchased with PIN codes - is also an essential mode of informal exchange. ${ }^{39}$ These phone minutes often become a liquid asset for cash-strapped prison economies, allowing prisoners to purchase a wide variety of goods. As such, cell phones and the markets they

\footnotetext{
${ }^{37}$ For work on call centres in Central America, see Kevin Lewis O'Neill, 'The Soul of Security: Christianity, Corporatism, and Control in Postwar Guatemala', Social Text, 30: 2 (2012), pp. 21-42.

${ }^{38}$ For general information on the rise of cell phone use in Guatemala, see Central America Data, 'Guatemala: Mobile Phone Market Figures' (2014), available at www.centralamericadata.com/en/article/ home/Guatemala_Mobile_Phone_Market_Figures (last access 11 July 2018).

${ }^{39}$ The Economist, 'Airtime is Money', The Economist, 19 Jan. 2013, available at www.economist.com/ news/finance-and-economics/21569744-use-pre-paid-mobile-phone-minutes-currency-airtime-money (last access 11 July 2018); Vivian Giang, 'Inmate Talks To Us Over an Illegal Cell Phone About Working the Jailhouse Black Market', Business Insider, 2 July 2012, available at www.businessinsider.com/prisonershares-with-us-a-glimpse-of-the-hustle-behind-bars-2012-6 (last access 11 July 2018).
} 
create make legible the multiple ways prisons and imprisoned men become anchored to their female visitors, as well as the kinds of entrepreneurial and emotional opportunities that such dependency makes possible for these women.

Most obviously, cell phones make familial and romantic relationships both possible and maintainable, helping to establish and sustain the romantic and business relationships that keep women coming back to prison. What is more, these phones are key vectors by which women's influence over prison life is sustained beyond their mere physical presence inside. '[Prisoners] spend all week in expectation of their next visit', explained a female social worker. 'They plan for it, prepare for it. A lot of guys don't have regular visits. But whether you have a visit or not, every guy is getting a haircut in preparation, washing the sector, cleaning up his cell.' Having worked inside Guatemala's largest prison for more than ten years, the social worker added: 'And they make phone calls all week long. "Are you going to come? When? What time?"

A cell phone even allowed Carlos and Sofía's relationship to take root. They first crossed paths in Canadá prison, which is located 60 kilometres south of Guatemala City. 'I didn't know anything about her', Carlos said. 'She went to go see somebody else, but she wasn't with that person, she was just working with him.' At the time, Sofía was moving small amounts of drugs into prison. 'So I see her, and I fall in love with her from far away. Damn! You know? That day I couldn't talk to her, or the next day. But one day I sent a guy over to see if she would give me her number. She said "no". She didn't give it to me. And so there it stayed.'

Sofía had plenty of other suitors. Prisoners - whether they deal in contraband or not - tend to be on the lookout for women who might help them. At the same time, some women visit prison in search of connexions that might prove profitable. After only a few months of moving drugs into prison, Sofía had received a number of business offers and romantic overtures, exemplifying the abundant opportunities that access to the prison makes possible for some women. She even received phone calls from prisoners whom she did not yet know. 'And they said to me', Sofía recalled, "“Oh Sofía, how are you?" And I was like, "My God, who could it be?” she laughed. “"Look, I don't know you”, I said, "I don't know you, and I don't know you."

Carlos did not have visiting privileges when he first met Sofía, and so their courtship happened almost entirely via cell phone. After Sofía refused his initial advance, Carlos kept in contact with Sofía by calling one of her girlfriends, who also occasionally smuggled contraband into the prison. Eventually, he caught her attention.

'But then all of a sudden we started talking', Sofía said. 'Because I was having trouble with the other person I was visiting.' Carlos prided himself on being a smooth talker, at least on the phone. 'It took a lot of courtship', he admitted, 'And I'm bad in person, but over the phone, I know how to make people trust me.' Two years as a customer service agent in the call centre had helped him hone his own skills at emotional labour, skills he came to rely on while running telephone-promotions scams with fellow prisoners. Carlos eventually won Sofía over at about the same time she decided to make a strategic business decision. 'After we talked', Sofía recalled, 'I said to my friend, "How I wish it had been him who received me [as a business partner in prison] the first time." She smiled: 'I would have preferred Carlos. Because he seemed like such a good person, peaceful 
and everything, you know? I really regretted it. Why wasn't it him!?' In a decision that entwined her entrepreneurial and romantic interests, Sofía partnered with Carlos.

Sofía and Carlos' relationship illustrates the complicated exchanges of emotional and material labour that cell phones make possible. 'We used to talk about our lives', he said, 'She used to ask me about my life. I never lied to her about anything. I used to ask her about her life. She really helped me out.' And, typical of the complex entanglements between romance and survival behind bars, such connexions were rarely just emotional. Prisoners' desperation and women's freedom of movement often mean emotional labour undergirds the material support women like Sofía provide for inmates like Carlos. Even before Carlos could receive visitors, Sofía started bringing him gifts, passing them through prison windows. At first she brought Carlos food, deodorant, razors and other legal goods. 'Then one time, I lost my phone', Carlos remembered. 'And I bought a new one. And she told me, "Stop buying them in there. I'm gonna take you one, OK?"' And so she did. Soon afterwards, he asked her to bring in another cell phone, which he then sold for a steep profit.

As their relationship deepened, Carlos' emotional instability and possessiveness began to complicate an already stressful situation, forcing Sofía to manage her business and her emotions in order to assuage his jealousy. He became jealous of Sofía's contact with other prisoners. 'I didn't like her working for other guys. I know how the thing goes.' Carlos was making an oblique reference to sex work. 'I told her, "You go into a prison and you gotta take [the phone] out [of your body], and the guys don't respect that."' He shrugged. 'I didn't respect that either.' Carlos' violent fits even began to structure their phone conversations until Sofía, to assure him of her devotion, destroyed all of her phone chips except for the one connected to Carlos. By cutting herself off from other business opportunities inside the prison, Sofía devoted herself to Carlos, but this was also the only way to make Carlos trust her intentions. 'That was how I knew it was for sure', Carlos admitted. 'Because she dropped everything for me. She stopped working. That's how she was making her money, taking shit to other places. When I told her I didn't like it, she said, "OK, I'll stop, and if I do it, I'll do it only for you." We were in it together.'

Despite his efforts to control her, Carlos' incarceration also allowed Sofía a degree of agency. In a society dominated by high levels of domestic violence, the ability to simply hang up on Carlos when he became verbally abusive, or refuse to visit him unless he changed his behaviour, markedly shifted ingrown gender dynamics. In this way, the prison can become, in the words of a female social worker, a 'rare space of freedom' for women who maintain relationships with imprisoned men. Sofía could always counter Carlos' demands, hang up on Carlos' phone calls and even decide not to visit as planned. La visita makes it legible how, in some instances, the transformation of power dynamics in male prisons makes it possible for women to walk away when they have had enough.

'She made me cut everything off, also', Carlos recalled. 'I had other connexions. I had other women, and she made me cut everything off. She's the only one.' To ensure that she would continue visiting him, Carlos also destroyed his phone chips except for the one that connected him to Sofía. The cell phone, by way of la visita, set the conditions for a deeply committed partnership. 


\section{The Prison Drug Economy}

Committed relationships and the cell phones that sustain them are also essential to bringing drugs into prisons. Both allow an expansive network of people to coordinate not simply their labour and affection but also their survival. Sofía and Carlos, for one, never worked alone. They committed themselves to each other, and their profits relied upon a combination of material and emotional labour on both sides of the prison gates. Cell phones, in this sense, allowed Sofía and Carlos to coordinate their trafficking operations while recommitting themselves to each other along the way - with text messages and phone calls that integrated their expressed love for each other with the logistics of moving illicit drugs into the prison setting. This dance of devotion and details forced Carlos to recognise the power that Sofía had over not just his emotional life, but also his survival and success in the prison drug economy.

The prison drug economy is key to the penitentiary system. Sixty per cent of Guatemalan prisoners use drugs, with marijuana by far the most commonly used and most widely welcomed drug in prison. Prison officials even consider marijuana 'not only necessary but required' to maintain a tranquil and orderly prison population. As one prison director stated, 'I know how much marijuana gets smuggled in here. But let them smoke their joints. It calms them down, makes the time pass. If I were to seize all the marijuana tomorrow, I would have an immediate riot on my hands.' The drug helps inmates relax and deal with day-to-day struggles and it certainly helped to manage Carlos' expectations. 'I smoke my joints just to forget the situation I'm in', Carlos said at the beginning of one of our interviews. It was 9 a.m., and he had just shared a joint with a fellow prisoner. 'It's the one drug I haven't tried to give up.' For there are other drugs. 'On certain days', explained another prisoner, 'It is easier to find crack in here than bread.' Carlos, a steady user himself, mentioned: 'Drugs is what surrounds you here. When I was in [pre-trial detention], there'd be a guy cooking crack next to me, another guy selling further down the corridor and another guy high in the corner.'

Trafficking marijuana and cocaine into prison can be lucrative. This is one reason why a few months into their relationship Sofía and Carlos began to expand their operations beyond cell phones. This meant a marked increase in the expenditure of Sofía's labour as she began to pack illicit drugs - typically marijuana and cocaine - for her and Carlos' growing business.

Typically, a woman smuggling drugs gets paid for quantity. ${ }^{40}$ Teo, another prisoner in Carlos' cell block, grew up working for his grandmother's prison-smuggling network. He then took over the family business. 'If a lady smuggles a half-pound of marijuana [into the prison]', he explained, 'she gets 150 quetzals (US\$28). If she smuggles a pound for me, she gets Q300-Q350 (US\$55). Now, if she enters a pound and a telephone, she'll be getting Q350, plus the value of the phone. And if you replace the telephone with a packet of cocaine, she'll be making like Q700 (US\$100).' The same incentives drove Sofía and Carlos' relationship. Given the risk and the profit margins, both the women and the prisoners had a vested interest in maximising the quantity smuggled into the prison on a single visit.

\footnotetext{
${ }^{40}$ For one of the most insightful analyses available, see Chris Garces, 'Denuding Surveillance at the Carceral Boundary', South Atlantic Quarterly, 113: 3 (2014), pp. 447-73.
} 
Increasing profits involves considerable material labour for women like Sofía. The first step is packing the drugs efficiently. Packing marijuana, the most popular prison drug, is time-consuming work. Sofía taught herself every step of this process. She prepared the marijuana in her family's home while her parents - both Evangelical Christians - were away at work. 'First, you take a pound or a half-pound of marijuana and cut it with scissors', she explained in her family's one-room house. 'Once that's done, I put it in a plastic bag inside another plastic bag wrapped in tape, and pound it over and over, twisting the bag to make it tighter. It starts off big, and I have to get it down to the size that I can manage.'

The next step is transport. Getting from her home to the prison typically took Sofía three and a half hours. First, she took a microbus downtown. There she would go into a public restroom. She would then remove the marijuana - or cell phone, or packets of cocaine - from her purse and insert it into her vagina. From there, it took two more potholed hours to get to the outer gate of the prison. Along the way she kept in contact with Carlos via texts, as he was nervous and eager to know her progress. After catching the bus from downtown towards the prison in May of 2014, for example, they had the following exchange:

Carlos:

Sofía:

Carlos:

Carlos:

Carlos (12 minutes later): Sofía:
'My love, I can't wait to touch you! Everything OK?'

'Almost to Zone 10, my love. It hurts a lot today!'

'You're amazing.'

'My heart beats only for you.'

'My love, where are you now?'

'On the Carretera El Salvador' (a main thoroughfare).

The buses stop at the perimeter of the prison and so visitors must make the long walk to the prison proper. To get to Pavón, it is a half-mile trudge along a rutted dirt road that turns to thick mud during the rainy season. Making this leg of the journey while loaded down with legal goods is difficult enough. Walking with illicit goods tucked inside the body is harder still. Sofía said that she could usually ignore the contraband inside her, though sometimes a packet of marijuana would heat up and become uncomfortable. But the true test always came during the inspection at the prison gates.

With war on drugs-inspired legislation governing Guatemalan prisons, those caught smuggling contraband face a stiff prison sentence. Navigating this risk requires painstaking preparation and self-control. Escaping detection requires hyperawareness and a meticulous manipulation of the body, emotions and social interactions to get past prison guards. While the Guatemalan prison system has no metal detectors, no drug-sniffing dogs and no imaging technology, prison guards do deploy full body-cavity searches at random. The arbitrariness of such searches makes passing undetected contingent upon not only careful strategy but also some degree of luck.

To escape detection, Sofía had to maintain both physical control and emotional discipline. 'Every time I go, I have to think about it', Sofía said. 'It's dangerous. There's a little room just for women. The guards are there with their latex gloves. They wear them all the time just to intimidate you. They have the glove on already just to see if you get nervous. If [the drugs are] not well-positioned, they will feel it, and it's "Ah ha!"' She snapped her fingers. 'I know, because I've seen it happen. And it's straight to the central office. Then they take your picture, and take you 
to the police.' Sofía took a moment to weigh the risk: 'If you really don't love the person', she said, 'I don't see why you would do it.'

Success, then, demands that the woman act the part of the innocent. But learning the subtleties of this performance takes practice. Sofía had to develop new skills and strategies of dissimulation. Knowing that other women smuggling for wellconnected competitors could inform on Sofía to the authorities, Carlos helped her to change her habits. 'I learned so many things with Carlos! Before, I would talk to others, using bad words, because that's how I expressed myself then', Sofía said. 'With Carlos, I started to change my vocabulary, using less bad words.' Carlos also convinced her to stop smoking because 'good girls don't smoke'. Sofía smiled: 'So, now when I come, I'm like, "Good day to you, and good day to you." With my baby in my arms. And me going through with my nerves on edge, but I show nothing. Only I know the pain I carry inside.' Here, acting the part of an innocent mother became a means by which Sofía could evade the state's suspicions and corporeal surveillance.

And yet there were other moments when Sofía had to push back against prison guards to ensure a smooth entry into Pavón. 'She was coming to visit me', Carlos explained, 'and they would know [that she was smuggling] because they all knew I had marijuana.' Despite his premonitions, he told her to bring a small cell phone charger, which she could hide more easily from a cavity search. Sofía recalled the encounter. 'One of the guards was like, "What do you have there, Miss?"

Sofía: 'Nothing. Stick your finger in me if you want.'

Officer: 'You have something there, Miss.'

Sofía: 'No, I don't have anything, and if you're gonna accuse me, accuse me well. And if not, then let me pass.'

Her bluff worked, and they let her pass. ${ }^{41}$ Although no ordinances dictate that female visitors undergo more severe scrutiny than their male counterparts, surveillance practices bear out a de facto misogyny. While women must always face the possibility of being subjected to a cavity search, men never receive more than a basic surface inspection that might entail a passing pat between the thighs, but nothing more. ${ }^{42}$

\section{Affection}

In prison, the circulation of material goods depends principally upon the circulation of affect. Consequently, the business of survival cannot be understood without

\footnotetext{
${ }^{41}$ See, for example, Judith Butler, 'Passing, Queering: Nella Larsen's Psychoanalytic Challenge', in Bodies That Matter: On the Discursive Limits of 'Sex' (New York: Routledge, 1993), pp. 161-180 and Valerie Smith, 'Reading the Intersection of Race and Gender in Narratives of Passing', diacritics 24: 2/3 (1994), pp. 43-57.

${ }^{42}$ The literature on machismo is substantial. See generally Matthew C. Gutmann, The Meanings of Macho: Being a Man in Mexico City, 10th anniv. ed. (Berkeley, CA: University of California Press, 2006); Roger N. Lancaster, Life is Hard: Machismo, Danger, and the Intimacy of Power in Nicaragua (Berkeley, CA: University of California Press, 1992); Sor Juana Inés de la Cruz, 'On Men's Hypocrisy', in Gilbert Joseph and Timothy Henderson (eds.), The Mexico Reader: History, Culture, Politics (Durham, NC: Duke University Press, 2002).
} 
considering the emotional and physical intimacies that la visita makes possible. Affection plays a powerful role in prison life, to the point of organising prison space, social relations, derivative economies and even life trajectories. Each visiting day, female visitors line up at prison gates well before dawn. Inside the prisons, as soon as guards complete the morning roll-call, prisoners gather as close to the outer gate as possible, craning their necks for a glimpse of an expected visitor. Their anticipation is potent, not least because heterosexual sex is an important part of prison culture.

Carlos recalled how desperate he was to have physical contact with Sofía after they started talking on the phone. 'We were waiting to just touch each other for a long time', Carlos said, but he didn't have permission for conjugal visits for the first month of their relationship. 'The first time I touched her was when they were giving us sun in the courtyard. I called her, told her, "Look we've got like two hours, if you can come." She rushed to the prison in time to give him a kiss. 'But that first kiss was like this', he mimed a dry-lipped peck on the lips. 'Later, on the phone, I was like, "What happened with your oh-so-romantic kiss?" And she was like, "No! I was nervous!"”

In prison, pursuing romance means making space for intimacy, which requires money. The state has built rooms reserved for conjugal visits, but demand outpaces the supply; and so in all but the few maximum-security facilities, prisoners construct makeshift tents in courtyards and organise a conjugal calendar to ensure that their cellmates have sufficient private time with their respective visitors. The isolation block where Carlos once lived, for example, is known as the módulo. The módulo was once the site of state executions. But the former death chamber, located at the far end of attached cells, has now become the most prized quarters, usually occupied by the leader of the cellblock. 'You'd think guys would be afraid because of ghosts', Carlos laughed, 'but it's the best room because you can be alone with a girl without other dudes barging through on the way to their own cell.' The premium on privacy can also include paying for childcare. 'You can't have children just wandering around while their parents caress each other!' exclaimed one prisoner-entrepreneur who capitalised on la visita. 'That's why I started a day-care.' He pointed across the courtyard at a cluster of prisoners dressed as clowns, capering about to entertain the children of both sex workers and prisoners.

But access to a space private enough for sex often costs a prisoner the equivalent of multiple days of legal-wage labour. This means that whether a conjugal visiting room is a part of the formal prison architecture or not, a prisoner must pay for the privilege of privacy. In El Preventivo prison, for example, prisoners pay Q20 (US $\$ 2.50$ ) for 15 minutes of privacy with their visitor inside state-built rooms. Given the scarcity of cash in the prison economy, some prisoners work all week just to raise enough money for this private time. The same price holds constant for prisoners renting informally constructed sites from other prisoners. 'A lot of guys don't have a nice space to share with their visitor', observed one prison social worker. She then gestured across the prison yard, at its haphazard collection of tents and informal structures. 'So they rent a room from a guy who does. And you do everything to ensure that things go well with her.'

Inmates' isolation and their deep dependence on the women who visit them can transform traditional understandings of gender dynamics. 'You see how women get 
treated here in Guatemala', Carlos mentioned, obliquely referencing the country's storied history of misogyny and machismo. 'Men treat women badly here in Guatemala. They don't listen to them, and just order them around. In the prison, it's different.' Carlos gestured at another prisoner with his arm wrapped around his visitor. 'Guys write love letters. They got nothing else to do, so they put all their energy into making nice with their lady.' La visita, then, compels many prisoners to treat these women with the kind of respect and affection often lacking on the outside. Most incarcerated men cannot financially support their visitors, which perhaps make them less willing to overstep the bounds of civility and respect. ${ }^{43}$ After all, once a visitor leaves, it is nominally up to her whether she answers his calls, or decides to return to the prison again. 'I can have my life on the outside', observed one woman during a visit to Canadá prison. 'And I can have my man here on the inside when I want him.' This curious trebling of gender makes the prison, at least for some women, a space of opportunity.

As a female social worker observed: "Watch the women cross the threshold of the prison.' She pointed at the gates: 'On the outside they are demure, staid, "yes, Sir", "no, Sir", good little women. But, as soon as they enter, something comes alive, something is awoken.' She put her hand to her chest. 'They find freedom. As soon as they cross the frontier of the prison, they can lose their etiquette. You won't be judged. No one will judge you ... On the street, you are under constant surveillance. In the prison, no one is watching. ${ }^{44}$

Romance also recalibrates business relationships, thrusting new trajectories onto already established agreements. A month into their relationship, Carlos got regular visiting privileges and Sofía was allowed to spend time with him in the módulo. Two months later, she was pregnant with their child. The pregnancy tied the two together even more tightly while extending indefinitely their shared horizon. Carlos, for one, became enmeshed in Sofía's family, promising to take responsibility for her other two kids. 'Her kids started calling me Dad', Carlos said. 'They call me Papito. They're not my kids, but I take care of them like my kids.' And, like many prisoners who conceive babies while inside prison, Carlos cited fatherhood as a primary reason for seeking an early release.

The pregnancy also projected their hopes for the future beyond the space of the prison. Both began to aspire towards a proper middle-class wedding and dreams of a good life, but making those dreams come true called for taking on more risk to afford a lawyer. In Guatemala, a growing proportion of prisoners remain behind bars well beyond their formal sentence because of bureaucratic delays that can often only be circumvented with professional legal help. Already closing in on the end of his sentence, Carlos became obsessed with contracting a lawyer to speed up the processing of his papers. In order to raise the money to pay a lawyer and provide for their growing family, Carlos and Sofía decided to increase their own rate of production by moving more cell phones and drugs into the prison. But Sofía struggled with her anxieties, resenting that their aspirations relied primarily on her shouldering more risk. 'No. I'm not going to get arrested for your sake', she recalled

\footnotetext{
${ }^{43}$ For perspectives on Latin masculinities, see Mara Viveros Vigoya, 'Contemporary Latin American Perspectives on Masculinity', Men and Masculinities, 3: 3 (2001), pp. 237-60.

${ }^{44}$ Fontes, Mortal Doubt: Transnational Gangs and Social Order in Guatemala City.
} 
telling Carlos. 'You want to stay here, fine. Not me. I understand now what it is to suffer in prison ... Being with you is like being a prisoner anyway.' But she saw no other option but to continue, clinging to the hope of a better future that she believed would only come after Carlos' release. 'I need the money', Sofía explained with some thoughtfulness, 'That's why I'm still thinking about it, but I don't know. I don't want to, but, like I said, the money is what calls right now and I really do need to get a move on with it because I have them', she nodded at her two children. 'And this one', she added, hugging the infant in her arms.

The problem is that powerful competitors within the prison drug economy have ways of keeping small-time traffickers from growing too big. Arguably the most effective strategy is manipulating the already established state surveillance and deterrence system at the prison gates. In their bid to raise enough money for Carlos' release, the two ended up attracting the attention of more powerful prison drug traffickers who in turn tipped off the guards about Sofía. In January of 2016, a few months before Carlos was set to be released, prison guards caught Sofía attempting to enter prison with a quarter-pound of marijuana inside her body. They took her photograph and fingerprints, booked her and charged her with drug trafficking.

\section{Conclusion}

As Guatemala and other Latin American countries continue to struggle with crime and underfunded, overpopulated prisons, it is important to assess how survival for prisoners and their communities on the outside depends upon breaking down the nominal boundaries separating the incarcerated from the free. In this article, we have focused on the crucial role of female visitors in providing essential commodities and care for male prisoners in Guatemala. Some find this role rewarding in emotional and financial terms, using their access to engage in affectionate, entrepreneurial opportunities. Their material and immaterial labour - inside the prison, at the prison gates and beyond the prison walls - effectively triages the state by upholding a prison system perpetually on the point of collapse. Linking imprisoned communities with life on the outside, criss-crossing the blurred boundaries between licit and illicit prison economies, the interdependencies that develop between these women and imprisoned men expose a carceral continuum that goes beyond state surveillance and carceral imaginaries to infiltrate the daily business of survival on both sides of prison walls.

This is a deeply gendered mode of survival. Female visitors, such as Sofía, must navigate considerable risks in order to reap a limited set of rewards. And though some visitors may enjoy a qualified sense of power, the potential consequences of their illicit labour reveal the structural inequalities and abuse underlying women's role in propping up prisons.

For Sofía, the potential consequences of her labour and her relationship were close at hand each time she visited Carlos. The long walk towards Pavón would take her past the Centro de Orientación Femenino (Women's Detention Centre, COF). This is Guatemala's largest female prison. At first glance, COF looks much like Pavón. It has 30-foot-high barbed-wire fences, an electrified barrier and armed guards, but the conditions of survival in Guatemala's female prisons are markedly different than in their male counterparts. The key distinction hinges on la visita. Whereas long lines of female visitors queue up several days a week 
outside male prisons, with women carrying not just bags of goods but also drugs and cell phones, there is rarely anyone waiting outside female prisons. As a prison social worker in COF commented, 'These days, it's mostly fathers who arrive, and grandfathers. Husbands are rare, and boyfriends almost never. This is an issue of machismo', she acknowledged, 'but also the fact that a lot of women get arrested along with their partner. That is, the man is involved in drug trafficking, and his woman gets arrested as an accomplice.'

In comparison with the state's treatment of male prisoners, the prison system exercises near total control over female prisoners. This control hinges on careful surveillance and regulation of their access to visitors. Whereas incarcerated men may receive multiple conjugal visits a week, state policy authorises conjugal visits only between husbands and their imprisoned wives. Conjugal visits may only commence after a documented record of consistent visits by the husband, with the man having to visit once every two weeks for six months to qualify for a conjugal visit. What is more, state policy also mandates that female prisoners must submit to monthly birth-control injections to ensure that those having sex do not get pregnant. And even when a woman's husband is not in prison, the pressures of poverty may make the state's requirements prohibitively difficult to fulfil. Visiting the prison is usually an all-day event that blocks a full day of work.

The lack of visitors has severe repercussions for female prisons. As we have shown, the licit and illicit goods that women transport into prison allow both male prisoners and female visitors to support themselves. In female prisons, these opportunities do not exist for either the prisoner or the visitor. There is no drug or cell phone market in which to participate. There are no prisoners tying endless knots to make hammocks to sell, for there is no one to bring them to market. Absent too is the panoply of auxiliary services which the conjugal visit inspires in male prisons: no one can make money inside a female prison by renting out a cell, or by running a restaurant that caters to dates between prisoners and their lovers. The lack of visitors and the absence of viable markets ultimately create a feedback loop that intensifies female prisoners' isolation.

Sofía suffered through this isolation. A sympathetic judge allowed her to plea down the charge of trafficking to one of possession of a controlled substance, and so she was given a one-year sentence that she served in La Preventiva. This is a prison in Quetzaltenango, which is located in the western highlands, roughly five hours outside of Guatemala City. She called La Preventiva 'the prison of the forgotten'. A former convent, the facility proved empty on visiting days, owing partly to the fact that most families could not travel five hours each way from Guatemala City for a onehour visit. There are also no conjugal visits. 'The men have it good', Sofía said, referring to her time in Carlos' prison. Sofía's parents tried to visit her when they could, but the long bus trip made it difficult, and they were barely getting by because her mother had stopped working to care for Sofía's three children. They came by only a handful of times during her incarceration, and only brought her oldest child. Her isolation was made even more difficult by the fact that, in La Preventiva, there was no work, no cell phones and no opportunities to make money. Some women made food and handicrafts to sell to visitors but, without a steady clientele, they ended up selling what they could to the guards. 'All I can think about is getting out of here to be with my kids again and help my family', she said. 'Maybe by 
working in a factory.' Sofía still wore an engagement band for Carlos, but the dream of their life together - a dream for which she had risked so much - had faded. 'I want to get out of here for my kids, for my parents, but not for Carlos.'

Six months into Sofía's sentence, Carlos was released, but he never came through on his promises to care for Sofía, their child or her family. He never visited her. Perhaps he had more immediate problems to deal with because, just before Sofía finished her own sentence, an unknown assailant shot him to death.

We spoke with Sofía shortly after her release in her family's home in Guatemala City. Her foray into prison smuggling, and the tempestuous relationship that set its unfortunate trajectory, had ended up leaving her and her family deeper in debt than when she began. She was struggling to find work to recoup the savings her parents had spent on her lawyer fees. All that Carlos had promised - marriage, a stable life together, caring for her and her family - had not materialised. But his death seemed to have softened Sofía's anger over his failures as a partner in business and in love. 'Carlos tried to help. I know he tried', she said as her two older boys gambolled about, and she hugged her youngest child, named after Carlos, to her chest. ' $\mathrm{He}$ just wanted what was best for us.'

This abrupt and violent conclusion to Carlos and Sofía's relationship provides a sobering reflection on la visita and the penitentiary system's reliance on women to sustain its mushrooming male prison population. While women ensure that imprisoned men will at least survive their time behind bars, no one seems to be able to stop the unprecedented levels of peacetime violence that have made Guatemala one of the most dangerous non-combat zones in the world. Efforts to create law and order through incarceration have only worsened the problem, while creating the conditions for women like Sofía to become entangled in the risks and rewards that la visita makes possible in male prisons. Drawn into the struggle for survival on both sides of the prison gates, these women become targets of state policies that, in essence, reproduce and reify widespread gendered prejudice and inequality that provoke some women to take on the risks of prison smuggling in the first place.

Acknowledgements. Fieldwork for this article was funded by the Social Science Research Council as well as the Harry Frank Guggenheim Foundation, the Open Society Foundations, the Social Sciences and Humanities Research Council of Canada, and the Wenner-Gren Foundation.

\section{Spanish abstract}

A partir en gran medida de investigaciones realizadas en el contexto norteamericano, los académicos que estudian las prisiones detallan las múltiples formas en las que las prácticas carcelarias se extienden más allá de las paredes de la prisión para transformar una gran variedad de espacios, evaluando al fin cómo los imaginarios carcelarios habitan los aspectos más íntimos de la vida cotidiana. En América Latina, esta división entre el adentro y el afuera de la prisión se resquebraja aún más cuando se examina desde la perspectiva de la supervivencia. A partir de una investigación etnográfica del sistema penitenciario guatemalteco, este ensayo explora cómo las profundas interdependencias que se desarrollan entre prisioneros masculinos y visitas femeninas dan sustento no sólo a estos prisioneros y sus visitantes sino a la misma prisión. 


\section{Portuguese abstract}

Estudiosos do sistema prisional, baseados em grande parte em pesquisa conduzida no contexto Norte-Americano, detalham as diversas maneiras com que práticas carcerárias se estendem para além dos muros das prisões e transformam uma ampla variedade de espaços, por fim analisando como imaginários carcerários existem nos mais íntimos aspectos da vida cotidiana. Na América Latina, esta divisão do dentro e do fora dos muros da prisão se esmiuçam ainda mais quando vistos sob a perspectiva da sobrevivência. Com base em pesquisa etnográfica dos sistema penitenciário da Guatemala, esse ensaio explora o quanto as interdependências que se desenvolvem entre os homens prisioneiros e mulheres visitantes sustentam não somente tais prisioneiros e visitantes como também o próprio sistema penitenciário.

Portuguese keywords: Guatemala; prisões; drogas; tráfico; mulheres

Cite this article: Fontes AW, O’Neill KL (2019). La Visita: Prisons and Survival in Guatemala. Journal of Latin American Studies 51, 85-107. https://doi.org/10.1017/S0022216X18000731 